\title{
Impact of Endoscopic Biliary Drainage on Intrinsic Hepatic Blood Flow in Human
}

\author{
MAHMOUD ALLAM, M.D.*; AHMED ATTIA, M.D.*; ESSAM EL SHIMI, M.D.*; \\ MOHAMED EL WARAKI, M.D.** and WESAM MORAD, M.D.*** \\ The Departments of Hepatology*, Interventional Radiology** and Epidemiology \& Preventive Medicine ***, \\ National Liver Institute, Menoufia University, Egypt
}

\begin{abstract}
Background: Obstructive jaundice affects a significant portion of people with injurious effect on the liver.

Aim of Study: The study aimed to study the impact of biliary drainage on hepatic blood follow.

Patients and Methods: This was a prospective study, conducted from January 2018 to December 2018. Thirty-six patients with biliary obstruction aged 21-72 years, 26 out of them have calcular obstructive jaundice, and the rest of the patients have malignant biliary obstruction. The majority of cases were non-cirrhotic (32 versus 4). Liver tests; (bilirubin level, alkaline phosphatase, GGT, albumin, INR, ALT and AST), and Kidney function tests (blood urea and serum creatinin) and $\mathrm{CBC}$ were done. Plus, other pre-ERCP assessments were done. Abdominal Ultrasonography (US) and Doppler study of portal and hepatic veins and hepatic artery with measurement of Hepatic artery Resistive Index (RI), Portal vein diameter and congestive index were done, CT and MRCP if indicated and ERCP for all patients. Two weeks after ERCP, all included patients underwent repetition of the same laboratory and Doppler US.
\end{abstract}

Results: Significant changes in patients' laboratories and in liver hemodynamics were noticed after biliary drainage.

The mean values of hepatic artery RI were significantly higher and mean values of portal vein maximum velocity (V max) were lower in studied patients before and after biliary drainage.

Conclusions: Liver hemodynamics measured by Doppler Ultrasound of hepatic artery RI \&V. max of portal vein may be a good predictor of liver injury in biliary obstruction.

Key Words: Endoscopic-Biliary drainage - Intrinsic - Blood Flow.

\section{Introduction}

BILIARY tract disorders of the affect a significant portion of the worldwide population, and the overwhelming majority of cases are attributable to

Correspondence to: Dr. Wesam Saber Morad, E-Mail: wesammorad@yahoo.com cholelithiasis or primary cholidechlithasis (gallstones). In United States; $20 \%$ of persons older than 65 years have gallstones with one million newly diagnosed cases are reported annually [1] .

Biliary obstruction often occurs in various diseases including migrating gallstones or pancreatic and hepato-cholangial tumors [2].

Un-treated biliary obstruction causes liver injury, cellular necrosis, bile ductular epithelial proliferation and activation of stellate cells followed by liver fibrosis and biliary cirrhosis $[3,4]$.

Possible causes of cholestatic liver injury are argued to hepatic expression of inducible Nitric Oxide Synthase (iNOS) and the marked increase blood level of endotoxin [5].

Nitric oxide induced by iNOS plays two opposite roles; while it protects the liver and other tissues, it could also cause impairments of these tissues [6,7]

The impairment of bile flow into the intestine enhances bacteria translocation across the intestinal mucosa and sometimes causes lethal endotoxemia $[8,9]$

Doppler ultrasound has prompted simple noninvasive and physiologic studies of liver hemodynamics. An excellent correlation between Doppler blood flow measurements and the values obtained with electromagnetic flow-metry indicates the accuracy and clinical use of Doppler estimation [10]. However, recent improvements in Doppler systems have make it possible to visualize the hepatic artery clearly [11].

It is well known that portal venous blood flow, but not hepatic arterial blood flow, is the major 
driving force for the development of atrophy/ hypertrophy complex of the liver [12,13] .

Other causes of hepatic artery enlargement include intra-hepatic arterio-venous shunting (vascular neoplasms), hereditary hemorrhagic telangectasia, and chronic active hepatitis [14]

Color and spectral Doppler are used in conjunction with grayscale imaging of to identify hepatic blood vessels and assess for presence and direction of flow. In addition, Doppler is used to evaluate the dynamics of flow within the vessel [15]

Liver diseases alter the liver parenchyma, which in turn, alters arterial blood flow, thus, Doppler studies should be performed to determine the parenchymal liver abnormalities. Once the presence of liver disease has been established, Doppler study can be used assess the severity of injury and to monitor progression [16-19].

\section{Aim of the study:}

We aimed to study the impact of successful endoscopic biliary drainage on the intrinsic hepatic blood flow measured by Doppler ultrasound in patients with biliary obstruction.

\section{Patients and Methods}

Study design:

This prospective study was conducted between January, 2018 and June, 2018. 36 patients with biliary obstruction aged $21-72$ years, 26 out of them had biliary obstruction secondary to CBD stones, the rest of the patients have biliary obstruction caused by malignant causes. The majority of cases were non-cirrhotic (32 versus 4). Through medical examination was done for all patients.

All included patients were subjected to the following:

Laboratory investigations: included liver tests (Bilirubin level, alkaline phosphatase and Gama Glutamyl Transpeptidase (GGT), albumin, prothrombin time, concentration and INR, alanine aminotransferase (ALT) and aspartate aminotransferase (AST), Kidney function tests (blood urea and serum creatinin) and complete blood count in addition to the other pre-ERCP procedure routine laboratory assessment.

Imaging: Abdominal ultrasonography (US) and Doppler study of portal and hepatic veins and hepatic artery with measurement of Hepatic artery Resistive Index (RI) \&Portal vein diameter and congestive index were done. All examinations were performed following overnight fasting. A combined ultrasonic B-mode/Doppler system (Toshiba Xairo
SSA-606A duplex system, Tokyo, Japan) with a sector-type probe was used for the ultrasonic evaluation. The CT and MRCP were done if indicated.

\section{C-Endoscopic Retrograde Cholangio- Pancreatography (ERCP):}

All included patients underwent drainage of obstructed biliary system through therapeutic Duodenoscope; Olympus, Exera TJF 190, Tokyo, Japan with use of different interventional procedures as lithotripsy, stenting or dilatation.

\section{III- Follow-up:}

Two weeks after ERCP procedures, all included patients underwent repetition of the same laboratory workup: Liver tests, Kidney function tests, Complete Blood Count (CBC). Abdominal ultrasonography (US) and Doppler study of portal and hepatic veins and hepatic artery with re-measurement of Hepatic artery Resistive index (RI) and portal vein diameter and congestive index were repeated.

\section{$I V$ - Ethical approval:}

The study started after approval of the scientific and ethical committee of our institute and a written consent was taken from each patient before starting the study.

\section{Statistical analysis:}

The patients' data before $\&$ after biliary drainage were collected, and analyzed using SPSS (statistical package for social science) version 26. In which descriptive statistics [e.g. percentage (\%), mean (X) and Standard Deviation (SD)] were done. Also analytical statistics using the following tests Student $t$-test and Mann Whitney U-test were done to compare mean value of two groups with quantitative variables either normally or non-normally distributed respectively. Also Wilcoxon Signed Rank tests were used to compare 2 pairs of measurements of quantitative data non-normally distributed variables. Spearman correlation $(r)$ was used to measure the association between two not normally distributed quantitative variables or one quantitative and one qualitative ordinal variable. And for all the above tests $p$-value of $<0.05$ was considered statistically significant.

\section{Results}

Demographics of studied patients according to age, gender, cause of biliary obstruction, associated viral hepatitis and symptoms at time of presentation were shown in (Table 1). Two weeks later the same laboratory and radiologic assessment was repeated for all enrolled patients (Table 2). Significant changes in patients' laboratories and in liver hemodynamics were noticed after biliary drainage. 
Correlation between changes of different patients' parameters with liver hemodynamics after biliary drainage and CBD diameter was shown in (Table 3).

The mean values of hepatic artery RI were significantly higher and mean values of portal vein maximum velocity (V. max) were lower in studied patients with liver cirrhosis before and after biliary drainage Figs. $(1,2)$.

Comparison between liver hemodynamics in patients with and without liver cirrhosis before and after biliary drainage was shown in (Table 4).

Correlation of changes of liver hemodynamics after biliary drainage with the initial cause of obstruction was shown in (Table 5).

Table (1): Descriptive statistics of studied variables.

\begin{tabular}{|c|c|c|}
\hline & Number of & $\begin{array}{l}\text { died patients } \\
6 \text { ) }\end{array}$ \\
\hline \multirow[t]{2}{*}{$\begin{array}{l}\text { Agelyear: } \\
\text { Mean } \pm \text { SD } \\
\text { Range }\end{array}$} & \multicolumn{2}{|c|}{$\begin{array}{c}45.56 \pm 16.58 \\
19-85\end{array}$} \\
\hline & No. & $\%$ \\
\hline \multicolumn{3}{|l|}{ Gender: } \\
\hline Male & 17 & 47.2 \\
\hline Female & 19 & 52.8 \\
\hline \multicolumn{3}{|c|}{ Cause of biliary obstruction: } \\
\hline Choledocholithiasis & 22 & 61.1 \\
\hline Benign stricture & 4 & 11.1 \\
\hline Pancreatic tumor & 3 & 8.3 \\
\hline Cholangiocarcinoma & 6 & 16.7 \\
\hline $\mathrm{HCC}$ & 1 & 2.8 \\
\hline \multicolumn{3}{|l|}{ Chronic HCV infection: } \\
\hline Positive & 4 & 11.1 \\
\hline Negative & 32 & 88.9 \\
\hline \multicolumn{3}{|l|}{ Chronic HBV infection: } \\
\hline Positive & 0 & 0.0 \\
\hline Negative & 36 & 100 \\
\hline \multicolumn{3}{|l|}{ Liver cirrhosis: } \\
\hline No & 32 & 88.9 \\
\hline Yes & 4 & 11.1 \\
\hline \multicolumn{3}{|l|}{ Diabetes mellitus: } \\
\hline No & 30 & 83.3 \\
\hline Yes & 6 & 16.7 \\
\hline \multicolumn{3}{|l|}{ Clinical presentations: } \\
\hline \multicolumn{3}{|l|}{ Fever: } \\
\hline No & 18 & 50.0 \\
\hline Yes & 18 & 50.0 \\
\hline \multicolumn{3}{|l|}{ Abdominal pain: } \\
\hline No & 3 & 8.3 \\
\hline Yes & 33 & 91.7 \\
\hline \multicolumn{3}{|l|}{ Jaundice: } \\
\hline No & 1 & 2.8 \\
\hline Yes & 35 & 97.2 \\
\hline
\end{tabular}

Table (2): Differences between laboratory investigations and radiological findings pre and post biliary drainage.

\begin{tabular}{clll}
\hline & \multicolumn{2}{c}{ The studied cases } & $\begin{array}{c}p^{-} \\
\text {N=36 }\end{array}$ \\
\cline { 2 - 3 } & value \\
\cline { 2 - 3 } & Before drainage & After drainage & \\
\hline ALT: & & & \\
X \pm SD & $98.28 \pm 52.37$ & $62.86 \pm 27.68$ & $<0.01$ \# \\
Range & $11-282$ & $16-131$ & \\
AST: & & & \\
X \pm SD & $107.69 \pm 79.53$ & $64.61 \pm 35.58$ & $<0.01$ \# \\
Range & $12-478$ & $14-170$ & \\
Bilirubin: & & & $<0.01$ \# \\
X \pm SD & $9.19 \pm 6.54$ & $3.19 \pm 2.30$ & \\
Range & $1.39-23.4$ & $0.6-8$ &
\end{tabular}

Alkaline

phosphatase:

$\begin{array}{llll}\mathrm{X} \pm \mathrm{SD} & 246.61 \pm 105.47 & 122.56 \pm 48.23<0.01 \# \\ \text { Range } & 95-684 & 67-297 & \end{array}$

$G G T$ :

$\begin{array}{llll}X \pm S D & 167.03 \pm 108.62 & 69.31 \pm 45.85 & <0.01 \# \\ \text { Range } & 47-579 & 10-199 & \end{array}$

Albumin:

$\begin{array}{llll}\mathrm{X} \pm \mathrm{SD} & 3.64 \pm 0.54 & 3.68 \pm 0.48 & 0.045 \\ \text { Range } & 2.3-4.5 & 2.5-4.4 & \end{array}$

Prothrombin

time:

$\begin{array}{llll}\mathrm{X} \pm \mathrm{SD} & 13.19 \pm 1.60 & 13.03 \pm 1.22 & 0.20 \\ \text { Range } & 11-16 & 11-15 & \end{array}$

WBCs:

$\begin{array}{llll}\mathrm{X} \pm \mathrm{SD} & 7130.6 \pm 3911.5 & 5225.0 \pm 2638.1 & <0.01 \# \\ \text { Range } & 3000-20800 & 3100-18000 & \\ \text { Platelets }\left(X 10^{3}\right): & & & \\ \mathrm{X} \pm \mathrm{SD} & 267.0 \pm 102.5 & 263.9 \pm 94.4 & 0.25 \\ \text { Range } & 120-641 & 122-580 & \end{array}$

$H b$ :

$\begin{array}{llll}\mathrm{X} \pm \mathrm{SD} & 11.5 \pm 1.1 & 11.98 \pm 0.98 & <0.01 \\ \text { Range } & 8.8-13.8 & 9.7-14 & \end{array}$

$R I:$

$\begin{array}{llll}\text { Mean } \pm \text { SD } & 0.63 \pm 0.06 & 0.60 \pm 0.05 & <0.01 \\ \text { Range } & 0.56-0.79 & 0.55-0.71 & \end{array}$

Range $\quad 0.56-0.79 \quad 0.55-0.71$

$V \max$ :

\begin{tabular}{llll} 
Mean \pm SD & $23.61 \pm 4.76$ & $32.36 \pm 5.58$ & $<0.01$ \\
Range & $13-31$ & $20-40$ & \\
CBD diameter: & & & \\
Mean \pm SD & $16.03 \pm 2.83$ & $5.92 \pm 1.93$ & $<0.01$ \\
Range & $12-25$ & $4-8$ & \\
\hline
\end{tabular}

\#: Wilcoxon test was used while other variables paired $t$-test was used to measure the association. 
Table (3): Spearman correlation between RI and V. max with age, laboratory investigations and CBD diameter readings pre and post biliary drainage.

\begin{tabular}{llllllllll}
\hline & \multicolumn{4}{c}{ RI } \\
\cline { 2 - 10 } Studied variables & \multicolumn{3}{c}{ Before drainage } & After drainage & Before drainage & After drainage \\
\cline { 2 - 11 } & \multicolumn{1}{c}{$r$} & $p$-value & $r$ & $p$-value & $r$ & $p$-value & $r$ & $p$-value \\
\hline Age & 0.66 & $<0.01^{* *}$ & 0.70 & $<0.01^{* *}$ & -0.38 & $0.02^{*}$ & -0.50 & $0.002^{* *}$ \\
ALT & -0.12 & 0.49 & 0.07 & 0.68 & 0.05 & 0.78 & 0.006 & 0.97 \\
AST & -0.21 & 0.23 & -0.11 & 0.51 & 0.11 & 0.53 & 0.12 & 0.50 \\
Bilirubin & 0.59 & $<0.01^{* *}$ & 0.61 & $<0.01^{* *}$ & -0.43 & $0.009 * *$ & -0.55 & $<0.01^{* *}$ \\
Alkaline phosphatase & 0.02 & 0.92 & -0.02 & 0.89 & -0.17 & 0.33 & -0.09 & 0.61 \\
GGT & -0.17 & 0.33 & -0.22 & 0.20 & -0.08 & 0.63 & 0.06 & 0.71 \\
Albumin & -0.38 & $0.02^{*}$ & -0.37 & 0.03 & 0.45 & $0.005 * *$ & 0.46 & $0.005^{*}$ \\
Prothrombin time & -0.16 & 0.35 & 0.11 & 0.51 & 0.22 & 0.19 & 0.05 & 0.38 \\
WBCs & 0.20 & 0.25 & 0.16 & 0.35 & -0.31 & 0.07 & -0.38 & $0.02^{*}$ \\
Platelets (X10 $\left.{ }^{3}\right)$ & -0.03 & 0.88 & -0.10 & 0.55 & -0.09 & 0.58 & -0.02 & 0.91 \\
Hb & -0.34 & 0.04 & -0.37 & $0.03 *$ & 0.44 & $0.007 * *$ & 0.36 & $0.03^{*}$ \\
CBD diameter & 0.07 & 0.67 & 0.05 & 0.77 & 0.05 & 0.79 & 0.07 & 0.69 \\
\hline
\end{tabular}

$r$ : Spearman's correlation coefficient.

Table (4): Association between radiological findings and cirrhosis in studied patients'.

Table (5): Association between causes of biliary obstruction and radiological findings before and after biliary drainage.

\begin{tabular}{|c|c|c|c|c|c|c|c|}
\hline & \multirow{2}{*}{\multicolumn{2}{|c|}{ Cirrhosis }} & \multirow{3}{*}{$\begin{array}{c}p- \\
\text { value }\end{array}$} & & & & \\
\hline & & & & & \multicolumn{2}{|c|}{ Cause of biliary obstruction } & \multirow{3}{*}{$\begin{array}{c}p- \\
\text { value }\end{array}$} \\
\hline & No $(\mathrm{N}=32)$ & Yes $(N=4)$ & & & Benign & Malignant & \\
\hline \multirow{4}{*}{$\begin{array}{l}\text { RI (before): } \\
\quad \text { Mean } \pm \mathrm{SD} \\
\text { Range }\end{array}$} & & & \multirow{4}{*}{$0.01 *$} & & $(\mathrm{~N}=26)$ & $(\mathrm{N}=10)$ & \\
\hline & $0.62 \pm 0.05$ & $0.70 \pm 0.02$ & & RI (before): & & & \multirow{3}{*}{$0.002 * *$} \\
\hline & $0.56-0.79$ & $0.69-0.72$ & & Mean \pm SD & $0.61 \pm 0.05$ & $0.68 \pm 0.06$ & \\
\hline & & & & Range & $0.56-0.72$ & $0.58-0.79$ & \\
\hline \multirow{3}{*}{$\begin{array}{l}\text { RI (after): } \\
\text { Mean } \pm \mathrm{SD} \\
\text { Range }\end{array}$} & $0.59 \pm 0.04$ & $0.68 \pm 0.02$ & \multirow[t]{3}{*}{$0.006 * *$} & RI (after): & & & \multirow{3}{*}{$0.001 * *$} \\
\hline & $0.55-0.71$ & $0.66-0.70$ & & Mean \pm SD & $0.58 \pm 0.04$ & $0.64 \pm 0.05$ & \\
\hline & & & & Range & $0.55-0.77$ & $0.57-0.71$ & \\
\hline \multirow{2}{*}{$\begin{array}{l}V \max \text { (before): } \\
\text { Mean } \pm \mathrm{SD} \\
\text { Range }\end{array}$} & $24.09 \pm 4.82$ & $19.75 \pm 1.5$ & \multirow[t]{2}{*}{0.06} & $V \max$ (before): & & & \multirow{2}{*}{$0.002 * *$} \\
\hline & $13-31$ & $19-22$ & & Range & $13-31$ & $16.3-22.0$ & \\
\hline \multirow{2}{*}{$\begin{array}{l}V \max (\text { after }): \\
\text { Mean } \pm \mathrm{SD} \\
\text { Range }\end{array}$} & $33.03 \pm 5.49$ & $27.0 \pm 2.94$ & \multirow[t]{2}{*}{$0.049 *$} & $\begin{array}{r}V \max (\text { after }): \\
\text { Mean } \pm \mathrm{SD}\end{array}$ & $34.57 \pm 4.65$ & $26.60 \pm 3.13$ & \multirow[t]{2}{*}{$<0.001 * *$} \\
\hline & $20-40$ & $23-30$ & & Range & $23-40$ & $20-30$ & \\
\hline
\end{tabular}

Mann Whitney test was used.

Mann Whitney test was used.
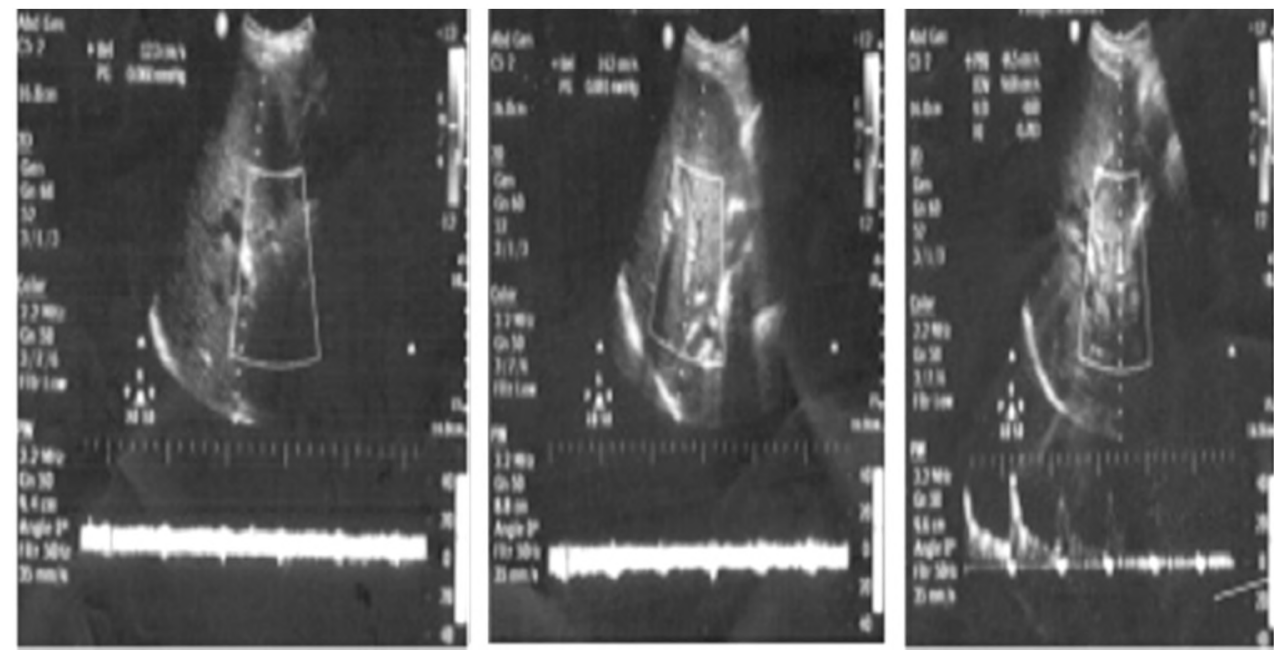

Fig. (1): (A,B,C): The resistivity index of hepatic artery was 0.77 , the Vmax of portal vein was $23 \mathrm{~cm} / \mathrm{sec}$ and the Vmax of hepatic vein was $37 \mathrm{~cm} / \mathrm{sec}$. 

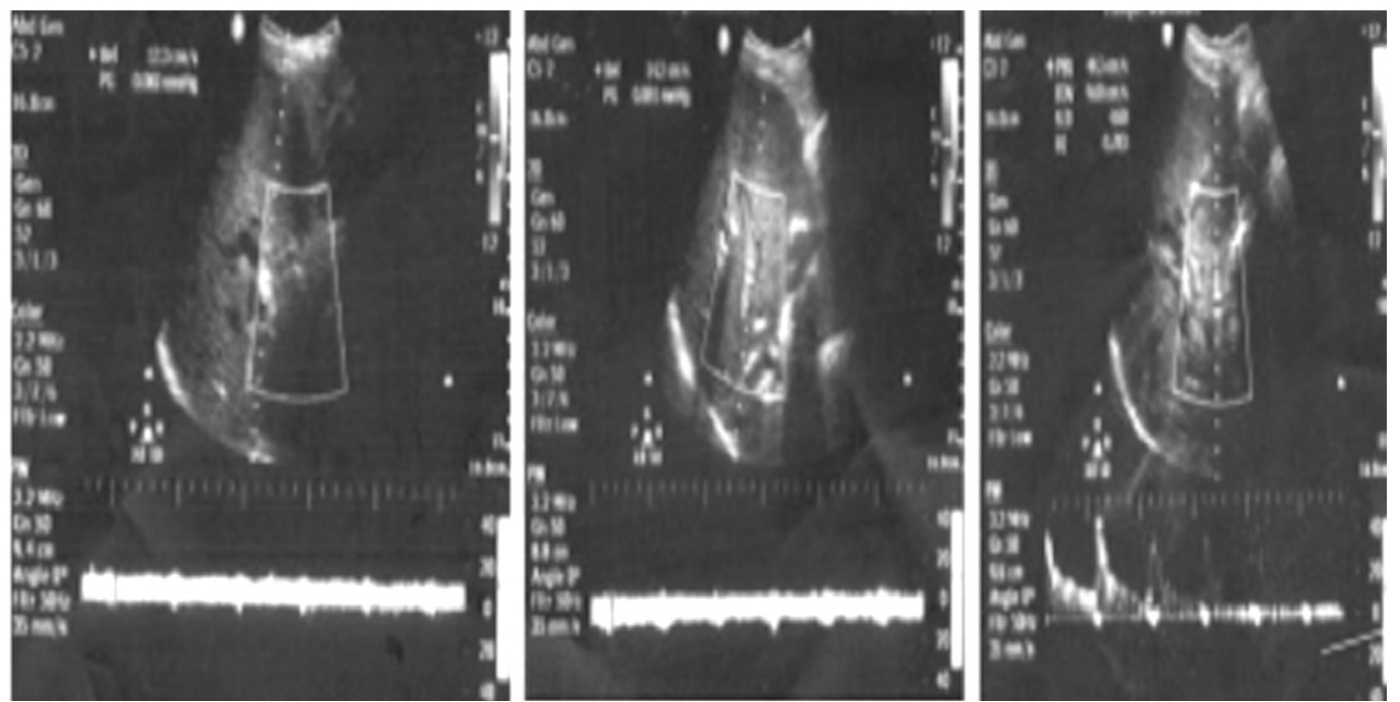

Fig. (2): (A,B,C): The resistivity index of hepatic artery was 0.7 , the $V \max$ of portal vein was $12.3 \mathrm{~cm} / \mathrm{sec}$ and the $\mathrm{V}$ max of hepatic vein was $14.2 \mathrm{~cm} / \mathrm{sec}$ (2 weeks after ERCP).

\section{Discussion}

National Liver institute-Menoufia University is a major tertiary referral center for Endoscopy and Liver diseases. We prospectively followed 36 patients with biliary obstruction; 17 patients $(47.2 \%)$ were males and females were $19(52.8 \%)$ and. Their ages ranged from 19 to 85 years with a mean of $45.56 \pm 16.58$ years.

Doppler US is a preferable imaging method because it is noninvasive, inexpensive, and easily repeatable and it can display hemodynamic changes easily by assessing the blood flow rate and flow characteristics [20]

In this study, we used color Doppler ultrasound system to determine the changes in hepatic hemodynamics after biliary drainage by measuring hepatic artery resistive index $\&$ portal vein maximum velocity.

In our series the etiology of obstructive jaundice was benign in $26(72.2 \%)$ cases; whereas 10 patients $(27.8 \%)$ had malignant causes. Choledocholithiasis was the commonest cause among the benign group in $22(61.1 \%)$ patients; whereas the commonest tumor among the malignant group was Cholangiocarcinoma in $6(16.7 \%)$ patients (Table 1).

In our study the efficacy of ERCP was considered sufficient when the diameter of the CBD decreased close to normal values $(8 \mathrm{~mm})$. The mean values of CBD diameter were $16.03 \pm 2.83 \mathrm{~mm}$ before drainage that decreased significantly to $5.92 \pm 1.93 \mathrm{~mm}$ in 14 days post ERCP $(p<0.001)$ (Table 1).
By correlation of different pre- $\&$ post-emptive parameters with changes in liver hemodynamics we found that: The mean values of the total serum bilirubin decreased significantly from $9.19 \pm 6.54$ $\mathrm{mg} / \mathrm{dl}$ to $3.19 \pm 2.30 \mathrm{mg} / \mathrm{dl}$ within 14 days following biliary drainage $(p<0.001)$ (Table 2$)$.

By correlating serum bilirubin with liver hemodynamics (RI \& V.max): A significant correlation between the rate of increase of V.max of portal vein \& decrease of R.I of hepatic artery and the rate of decrease of total bilirubin $(p<0.001)$ (Tables $2,3)$.

Hemoglobin level and WBCs count significantly improved after biliary drainage and decrease of resistive index. This can be argued to effect of restoration of bile flow back to the gut. Biliary drainage improves the patient quality of life and increases appetite. Also, there was significant correlation between the reduction of CBD after biliary drainage and increase of V.max of portal vein (Table 3 ).

The decrease of liver enzymes (ALT, AST, ALP and GGT) after biliary drainage did not correlate with the increase of V.max of portal vein and decrease RI of hepatic artery (Tables 2,3).

In our series the changes occurred in liver hemodynamics didn't correlate with changes occurred in CBD diameter after drainage (Tables $2,3)$.

In our study; the mean hepatic artery Resistive Index (RI) was $0.70 \pm 0.02$ in cirrhotic patients which was significantly greater than in non-cirrhotic and decreased after drainage (Table 4). 
The mean values of hepatic artery resistive index in patients with cirrhosis were greater than in patients without cirrhosis pre-\& post biliary drainage (Table 4).

Also the mean value of $\mathrm{V}$. max of portal vein in cirrhotic patients was $0.68 \pm 0.02 \mathrm{~cm} / \mathrm{s}$. It increased significantly to $27.0 \pm 2.94 \mathrm{~cm} / \mathrm{s}$ post-drainage (Table 4).

In this study, the mean value of $\mathrm{V}$ max increased significantly after drainage with significance $(p<0.001)$. These results agree with results of Kanda et al, who stated that V. max increase after 14 days of biliary drainage [21]. Gaiani et al., demonstrated a significant difference between cirrhotic and non-cirrhotic cases in terms of Portal Vein Velocity (PVV) [22].

In this study: By correlating the serum bilirubin with liver hemodynamics; RI \& V.max, we demonstrated a correlation between the rate of increase of V. max of portal vein \& decrease of R.I of hepatic artery and the rate of decrease of total bilirubin $(p<0.001)$ (Tables 2,3).

Also, we found a significant decrease of liver enzymes (ALT, AST, ALP and GGT) after biliary drainage with the increase of $\mathrm{V}$. max of portal vein and decrease RI of hepatic artery after biliary drainage (Table 2).

On the same way, the decrease in CBD diameter correlated with changes of liver hemodynamics after drainage. The study showed there was no correlation between patients with hepatitis infection $\&$ changes in liver hemodynamics after biliary drainage.

By correlating causes of biliary obstruction with changes in liver hemodynamics, there was a positive correlation between the degree of increase of V.max of portal vein \& decrease of RI of hepatic artery with the initial cause of biliary obstruction. And by correlating changes occurred in liver hemodynamic (RI \&V.max) after biliary drainage with the initial cause of biliary obstruction, we found a significant correlation between the rate of increase of V.max of portal vein \& decrease of R.I of hepatic artery with the causes of biliary obstruction (Table 5).

We lack similar results in human, however many authors found similar data in animal world $[\mathbf{9 , 1 8 , 2 3 - 2 9 ]}$

Possible explanation of the above studied hemodynamic changes came from a study done by Dias et al., who studied the effect of biliary ob- struction in rats. They found that biliary obstruction causes morphologic and functional alterations of the liver function, plus a concomitant reduction in portal flow and increase of plasma NO and hepatic tissue malondialdehyde [29].

The limitations of our study included small number of patients and some of the studied patients were cirrhotic that might affect the hemodynamics of blood flow of the liver.

\section{Conclusions:}

Biliary obstruction can cause liver injury in different ways. Liver hemodynamics measured by ultrasound Doppler of hepatic artery RI \& V.max of portal vein may be a good predictor of liver injury before and its improvement after biliary drainage in patients with extrahepatic biliary obstruction.

The clinical implications could be postulated for centers with high volume ERCP examination to decrease the waiting time for patients with biliary obstruction as much as possible to minmize liver injury associated with biliary obstruction.

\section{References}

1- CENTER S.A.: Diseases of the gallbladder and biliary tree. Vet. Clin. North Am. Small Anim. Pract. May, 39 (3): 543-98, 2009.

2- HOFMANN A.F.: Cholestatic liver disease: Pathophysiology and therapeutic options. Liver, 22: 14s-19s, 2002.

3- SCOBIE B.A. and SUMMERSKILL W.H.: Hepatic Cirrhosis secondary to obstruction of the biliary system. Am. J. Dig. Dis., 10: 135-46, 1965.

4- KOUNTOURAS J., BILLING B.H. and SCHEUER P.J.: Prolonged bile duct obstruction: A new experimental model for cirrhosis in the rat. Br. J. Exp. Pathol., 65: 30511, 1984.

5- WEI C.L., HON W.M., LEE K.H., et al.: Temporal expression of hepatic inducible nitric oxide synthase in liver cirrhosis. World J. Gastroenterol., 11: 362-7, 2005.

6- RAI R.M., LEE F.Y., ROSEN A., et al.: Impaired liver regeneration in inducible nitric oxide synthase deficient mice. Proc. Natl. Acad. Sci. U.S.A., 95: 13829-34, 1998.

7- THIEMERMANN C., RUETTEN H., WU C.C., et al.: The multiple organ dysfunction syndrome caused by endotoxin in the rat: Attenuation of liver dysfunction by inhibitors of nitric oxide synthase. Br. J. Pharmacol., 116: 2845-51, 1995.

8- GOUMA D.J., COELHO J.C., SCHLEGEL J.F., et al.: The effect of preoperative internal and external biliary drainage on mortality of jaundiced rats. Arch. Surg., 122: 731-4, 1987.

9- DING J.W., ANDERSSON R., SOLTESZ V., et al.: The role of bile and bile acids in bacterial translocation in obstructive jaundice in rats. Eur. Surg. Res., 25: 11-9, 1993. 
10- MORIYASU F., BAN N., NISHIDA O., et al.: Clinica application of an ultrasonic duplex system in the quantitative measurements of portal blood flow, JCU, 14: 57988, 1986.

11-SABBÀ C., MERKEL C., ZOLI M., et al.: Interobserver and interequipment variability of echo-Doppler examination of the portal vein: Effect of a cooperative training program. Hepatology, 21: 428-33, 1995.

12- ROUS P. and LARIMORE L.D.: Relation of the portal blood to liver maintenance. J. Exp. Med., 31: 609-32, 1920.

13- SCHWEIZER W., DUDA P., TANNER S., et al.: Experimental atrophy/hypertrophy complex (AHC) of the liver: Portal vein, but not bile duct obstruction, in the main driving force for the development of AHC in the rat. $\mathrm{J}$. Hepatol., 23: 71-8, 1995.

14- JEFFREY R.B. and RALLS P.W.: Sonography of the Abdomen, pp 150-71. New York, Raven Press, 1995.

15- SHEINFIELD M.H., BILALI A. and KOENIGSBERG M.: Understanding the spectral Doppler waveform of the hepatic veins in health and disease. Radiographics, 29: 2081-98, 2009.

16-McNAUGHTON D.A. and ABU-YOUSEF M.M.: Doppler US of the liver made simple. Radiographics, 31: 161-88, 2011.

17- SU Z.Z., SHAN H., KE W.M., et al.: Portal systemic hymodynamic changes in chronic severe hepatitis B: An ultrasonographic study. World J. Gastroenterol., 14: 7959, 2008.

18- VITAL A., BIOULAC-SAGE P., IRON A., et al.: Morphologic structure of bile canaliculi after bile duct ligation in the rat. A time-course study. Arch. Pathol. Lab. Med., 106: 464-7, 1982

19- KARVONEN J., KAIRISTO V. and GRÖNROOS J.M.: Stone or stricture as a cause of extrahepatic cholestasisdo liver function tests predict the diagnosis? Clin. Chem. Lab. Med., 4 (12): 1453-6, 2006.

20- MWANZA T., MIYAMOTO T., OKUMURA M., et al.: Ultrasonographic evaluation of portal vein hemodynamics in experimentally bile duct ligated dogs. Jpn. J. Vet. Res., 45: 199-206, 1998.

21- KANDA H., NIMURA Y., YASUI A., et al.: Hepatic blood flow after acute biliary obstruction and biliary drainage in conscious dogs, 1996

22- GAIANI S., GRAMANTIERI L., VENTUROLI N., et al.: What is the criterion for differentiating chronic hepatitis from compensated cirrhosis? A prospective study comparing ultrasonography and percutaneous liver biopsy. J. Hepatol., 27: 979-85, 1997.

23- WILLEMS B., VILLENEUVE J. and HUET P.: Effect of propranolol on hepatic and systemic hemodynamics in dogs with chronic bile duct ligation. Hepatology, Jan.Feb., 6 (1): 92-7, 1986.

24- OKADA Y.: Experimental study on the interruption of hepatic blood flow in obstructive jaundice, with special reference to the causes of death and prolonged jaundice after biliary decompression. Nihon GekaHokan May 1; 58 (3): 275-88, 1989.

25- KITAGAWA Y., NIMURA Y., KANDA H., UEMATSU T., et al.: The effects of intravenously infused catecholamines on hepatic blood flow in conscious dogs with experimental obstructive jaundice. Surg. Today, 26 (1): 21-8, 1996.

26- KANDA H., NIMURA Y., YASUI A., UEMATSU T., et al.: Hepatic blood flow after acute biliary obstruction and drainage in consciousdogs. Hepatogastroenterology. Jan.Feb., 43 (7): 235-40, 1996.

27- MIYAMOTO T., OKUMURA M., KADOSAWA T. and FUJINAGA T.: Ultrasonographic evaluation of portal vein hemodynamics in experimentally bile duct ligated dogs. Jpn. J. Vet. Res., Feb., 45 (4): 199-206, 1998.

28- JORGE G.D., TÁRTARO R.D., FACIN A.C., PEREIRA R.A., et al.: Late biliary obstruction in Wistar rats after intermittent hepatic pedicle clamping. Transplant. Proc. Jul.-Aug., 46 (6): 1875-8, 2014.

29- DIAS M., CENEVIVA R., ELIAS J., ZUCOLOTO S., et al.: Liver histological, portal flow and plasmatic nitric oxide alterations caused by biliary obstruction and drainage in rats. Acta Cir. Bras., 23 (Suppl 1): 2-7, 2008. 


\section{تآثير الصرف الصفراوى بالمنظار

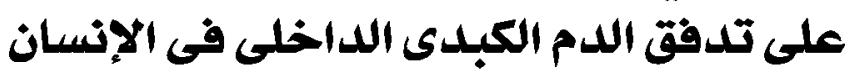

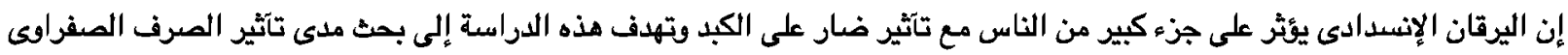

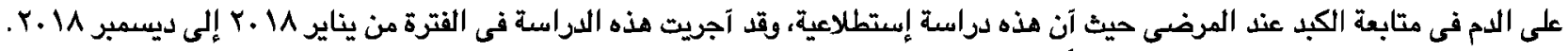

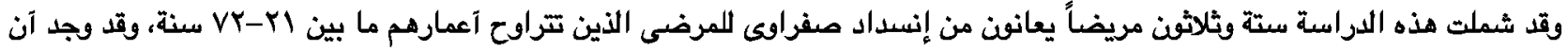

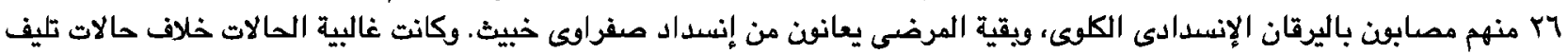

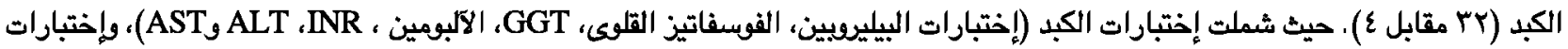

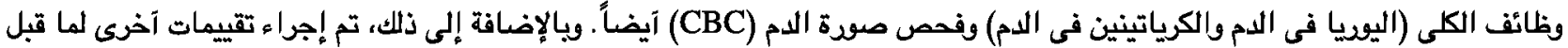

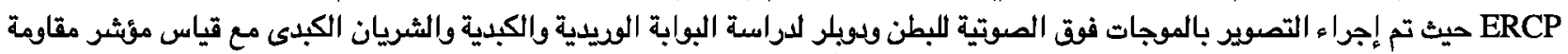

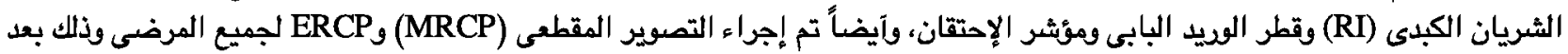
إسبوعين من عمل ERCP، حيث خضع جميع المرضى المشمولين فى الدراسة لتكرار نفس التحاليل المعملية السابق ذكرها وDoppler US.

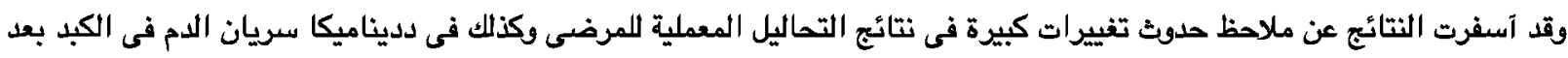

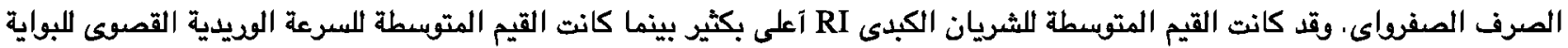

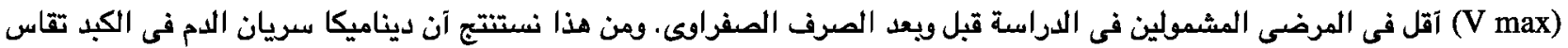

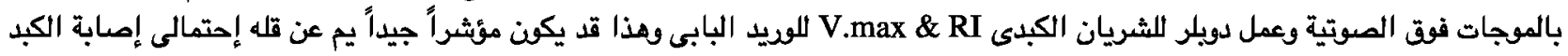
بالإنسداد الصفراوىى. 